\title{
FONTANUS PUBLICATIONS
}

\author{
FONTANUS (JOURNAL) \\ v. 1988 \\ v.2 1989 \\ v.3 1990 \\ v.4 1991 \\ v.5 1992 Montreal 350th Anniversary Issue \\ v.6 1993 Redpath Issue \\ v.7 1994 Stephen Leacock Issue \\ v.8 1995 Women in the University Issue \\ v.9 1996 McGill 175th Anniversary Issue \\ v.10 1998 Rutherford Centenary Issue \\ v.11 2003
}

\section{FONTANUS MONOGRAPH SERIES}

Adam Gacek, Arabic Manuscripts in the Libraries of McGill University, Union Catalogue, 1991

Calvin Evans, Sõren Kierkegaard Bibliographies: Remnants 1944-1980 and Multi-Media, 1925-1991, 1993

Barbara Lawson, Collected Curios: Missionary Tales from the South Seas, 1994

A. J. Hobbins, On the Edge of Greatness: The Diaries of John Humphrey, First Director of the United Nations Division of Human Rights, Vol. 1, 1948-1949, 1994

Max Dunbar, Essays from a Life: Scotland, Canada, Greenland, Denmark, 1995

Alberto Péréz-Goméz and Louise Pelletier, Anamorphosis: An Annotated Bibliography with Special Reference to Architectural Representation, 1995

Adam Gacek, Arabic Lithographed Books in the Islamic Studies Library, McGill University, Descriptive Catalogue, 1996

Irena Zantovská Murray, Sources in Iconography in the Blackader-Lauterman Library of Architecture and Art, McGill University, An Annotated Bibliography, 1995

A.J. Hobbins, On the Edge of Greatness: The Diaries of John Humphrey, First Director of the United Nations Division of Human Rights, Vol. 2, 1950-1951, 1996

Joan C. Bevan and Maria A. Pacelli, The Quintessential Canadian Anaesthetist: Wesley Boume. A Retrospective on the Foundation of McGill Anesthesia, 1996

Goldie Sigal, A Garment Worker's Legacy: The Joe Fishstein Collection of Yiddish Poetry, 1998

A.J. Hobbins, On the Edge of Greatness: The Diaries of John Humphrey, First Director of the United Nations Division of Human Rights, Vol. 3, 1952-1957, 1998

A. J. Hobbins, On the Edge of Greatness: The Diaries of John Humphrey, First Director of the United Nations Division of Human Rights, Vol. 4, 1958-1966, 2000

Orders may be placed at: Marketing Department

McGill-Queen's University Press

3430 McTavish Street

Montreal QC, Canada H3A 1X9 

(3) AGMV Marquis

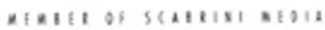

Quebec, Canada 2003 
